\title{
Metabolic effects of intravenous salbutamol in the course of acute severe asthma
}

\author{
S. G. NOGRADY, J. P. R. HARTLEY, AND A. SEATON
}

From the Asthma Research Unit, Sully Hospital, and Department of Tuberculosis and Chest Diseases, Welsh National School of Medicine

Nogrady, S. G., Hartley, J. P. R., and Seaton, A. (1977). Thorax, 32, 559-562. Metabolic effects of intravenous salbutamol in the course of acute severe asthma. Peak expiratory flow rate and plasma free fatty acids, potassium, insulin, and glucose were measured in 10 patients admitted with acute severe asthma before and at frequent intervals for one hour after an infusion of salbutamol, $4 \mu \mathrm{g} / \mathrm{kg}$ over 10 minutes. These studies were repeated during the recovery phase and again before discharge. Effective bronchodilatation seen after the infusion was similar in the acute and recovery phases. Baseline plasma free fatty acids were elevated but rose significantly after the infusion. There was also a significant fall in plasma potassium. These changes occurred in all individuals. There were no significant differences in mean baseline or peak changes of plasma free fatty acids, potassium or insulin on any of the study days. There was no evidence of $\beta$ receptor blockade in the acute phase in any patient.

Bronchodilators and corticosteroids are essential therapy in acute severe asthma. Since corticosteroids take several hours to produce their effects, the early use of bronchodilators is vital. Both inhaled and intravenous bronchodilators are commonly used, and recently intravenous salbutamol has been shown to be at least as effective as aminophylline (Williams et al., 1975; Johnson et al., 1976). Moreover, there is evidence that, in patients with particularly severe attacks of asthma, the inhalational route is less effective than the intravenous (Williams and Seaton, 1977).

The optimum dose of salbutamol is not yet established, although there is a tendency both in severe asthma and in obstetrics to use increasingly large doses (Liggins and Vaughan, 1973; May et al., 1975).

After $\beta$ sympathetic stimulation, elevation of plasma free fatty acid levels and a fall in plasma potassium as well as changes in insulin and glucose levels have been reported in normal subjects (Goldberg et al., 1975) and asthmatics (Tickner et al., 1977). In view of the $\beta$ stimulant effects of salbutamol it is important to establish whether its metabolic actions are likely to be of clinical significance in severe asthma.

We have therefore studied the effects of the intravenous administration of salbutamol to patients with severe acute asthma on admission and during recovery on plasma free fatty acids, potassium, insulin, and glucose.

\section{Patients and methods}

Ten patients with a severe acute exacerbation of asthma refractory to their usual treatment ('status asthmaticus') gave informed consent to the study. All had previously demonstrated reversibility of airways obstruction, as measured by a greater than $15 \%$ improvement in peak expiratory flow rate (PEFR) with bronchodilators. All were admitted in a severe attack (pulse rate $>110$ per minute, PEFR $<25 \%$ of predicted normal, $\mathrm{PaO}_{2}<9 \cdot 3 \mathrm{kPa}$ $(<70 \mathrm{mmHg})$ ). Patients who had received parenteral sympathomimetics within two hours before admission and patients with diabetes mellitus or gross obesity were not included. Seven of the patients were on maintenance treatment with prednisone before admission.

Baseline observations of pulse rate, PEFR (as the best of three recordings with a Wright's peak flow meter), and arterial blood gases were made PEFRs too low to record on the peak flow meter were measured as 60 litres/minute. Plasma for estimation of free fatty acids (FFA), glucose, insulin, and potassium was obtained. 
Plasma free fatty acids were measured by the fluorimetric method of Carruthers and Young (1973). Plasma insulin was measured by the double antibody technique and radioimmunoassay (Radiochemical Centre, Amersham). Plasma potassium was measured by flame photometry, and glucose was estimated by the glucose oxidase method.

Salbutamol, $4 \mu \mathrm{g} / \mathrm{kg}$, was given intravenously over 10 minutes by constant infusion pump. Serial measurements of PEFR and plasma for analysis were obtained at $5,10,15,20,30,45$, and 60 minutes after the beginning of infusion.

After initial investigations patients were started on a standard treatment with oxygen and hydrocortisone, $1 \mathrm{~g}$ immediately and $500 \mathrm{mg}$ every six hours. Antibiotics were given when appropriate. Treatment with salbutamol, steroids, and oxygen was modified according to the patient's response during his stay in hospital.

The salbutamol infusion, as well as the measurements made previously, were repeated three days later and again before discharge. Bronchodilators were withheld for six hours, and patients were fasted overnight before each study. The results were analysed by Student's $t$ test for paired samples.

\section{Results}

\section{PEAK EXPIRATORY FLOW RATE}

As expected, PEFR was lowest on admission and rose throughout hospitalisation in all patients. Effective bronchodilatation, as measured by the mean maximum percentage increase in PEFR after the salbutamol infusion, was approximately $50 \%$ on each of the three days (Table 1 ).

The onset of bronchodilatation occurred within five minutes, reaching a peak at $20 \pm 11$ minutes $($ mean $\pm S D)$. It fell thereafter to reach only $68 \%$ of the peak at 60 minutes.

\section{FREE FATTY ACIDS}

The mean baseline free fatty acid levels were raised on all three days, though at the time of

Table 1 Changes in PEFR after salbutamol infusion in acute and recovery phases

\begin{tabular}{|c|c|c|c|}
\hline & $\begin{array}{l}\text { Mean baseline } \\
\text { PEFR }(l / \mathrm{min})\end{array}$ & $\begin{array}{l}\text { Mean maximum } \\
\% \text { increase in } \\
P E F R\end{array}$ & $\begin{array}{l}\mathbf{P} \\
\text { (baseline } \\
\mathrm{v} \text { max }\end{array}$ \\
\hline $\begin{array}{l}\text { Admission } \\
\text { Day } 3 \\
\text { Discharge } \\
\text { P (admission } \\
\quad v \text { day } 3 \text { ) } \\
\text { P (admission } \\
v \text { discharge) }\end{array}$ & $\begin{array}{c}82 \pm 23 \\
175 \pm 70 \\
262 \pm 118 \\
<0.002 \\
<0.001\end{array}$ & $\begin{array}{l}53 \pm 27 \\
51 \pm 20 \\
45 \pm 29 \\
\text { NS } \\
\text { NS }\end{array}$ & $\begin{array}{l}<0.05 \\
<0.05 \\
\text { NS }\end{array}$ \\
\hline
\end{tabular}

discharge had fallen almost to the normal range of 315-600 $\mu \mathrm{mol} / 1$ (Dole, 1956). However, the differences between mean baseline levels on the three study days were not significant (Table 2).

After the infusion values rose significantly in all patients on three days, the response not differing between acute and recovery days. Individual peak values on each day were 2757,2231 , and $2300 \mu \mathrm{mol} / 1$. The mean time taken to reach peak values was $22 \pm 14$ minutes.

Table 2 Changes in plasma free fatty acids after salbutamol infusion in acute and recovery phases

\begin{tabular}{llll}
\hline & $\begin{array}{l}\text { Mean baseline } \\
(\mu \mathrm{mol} / \mathrm{l})\end{array}$ & $\begin{array}{l}\text { Mean peak } \\
(\mu \mathrm{mol} / \mathrm{l})\end{array}$ & $\mathrm{P}$ \\
\hline Admission & $1104 \pm 482$ & $1681 \pm 527$ & $<0.05$ \\
$\begin{array}{l}\text { Day 3 } \\
\text { Discharge }\end{array}$ & $1122 \pm 357$ & $1823 \pm 483$ & $<0.002$ \\
$\begin{array}{l}\text { P (admission } \\
\quad \begin{array}{l}\text { day 3) } \\
\text { (admission }\end{array}\end{array}$ & $\mathrm{825} \pm 355$ & $1491 \pm 470$ & $<0.01$ \\
$\quad \mathrm{~N}$ discharge) & $\mathrm{NS}$ & $\mathrm{NS}$ & \\
\hline
\end{tabular}

POTASSIUM

There were no significant differences between mean baseline plasma potassium levels on any of the study days. Values were at the lower limit of the normal range. After the salbutamol infusion plasma potassium fell significantly in all patients on the three days (Table 3). Individual lowest values occurred in patients whose baseline values were lowest and were $2.73,2.87$ and $2.79 \mathrm{mmol} / 1$ on each of the study days respectively. The mean time taken to reach lowest values was $25 \pm 15$ minutes. By 60 minutes potassium levels had returned almost to baseline values.

Table 3 Changes in plasma potassium after salbutamol infusion in acute and recovery phases

\begin{tabular}{|c|c|c|c|}
\hline & $\begin{array}{l}\text { Mean baseline } \\
(\mathrm{mmol} / \mathrm{l})\end{array}$ & $\begin{array}{l}\text { Mean lowest } \\
\text { value }(\mathrm{mmol} / \mathrm{l})\end{array}$ & $\mathbf{P}$ \\
\hline $\begin{array}{l}\text { Admission } \\
\text { Day } 3 \\
\text { Discharge } \\
\text { P (admission } \\
\quad v \text { day } 3 \text { ) } \\
\text { P (admission } \\
\quad v \text { discharge) }\end{array}$ & $\begin{array}{l}3 \cdot 72 \pm 0 \cdot 31 \\
3 \cdot 80 \pm 0 \cdot 37 \\
4 \cdot 02 \pm 0 \cdot 40 \\
\text { NS } \\
\text { NS }\end{array}$ & $\begin{array}{l}3 \cdot 27 \pm 0 \cdot 27 \\
3 \cdot 24 \pm 0 \cdot 27 \\
3 \cdot 55 \pm 0 \cdot 30 \\
\text { NS } \\
\text { NS }\end{array}$ & $\begin{array}{l}<0.002 \\
<0.01 \\
<0.002\end{array}$ \\
\hline
\end{tabular}

INSULIN

Baseline plasma insulin levels tended to be slightly higher on admission than those on later study days, although this was not statistically significant. After the infusion of salbutamol, plasma insulin 
Table 4 Changes in plasma insulin and glucose after salbutamol infusion in acute and recovery phases

\begin{tabular}{|c|c|c|c|c|c|c|}
\hline & $\begin{array}{l}\text { Mean baseline } \\
\text { plasma insulin } \\
\text { (u units } / m l)\end{array}$ & $\begin{array}{l}\text { Mean peak } \\
\text { plasma insulin } \\
\text { (u units/ml) }\end{array}$ & $\mathbf{P}$ & $\begin{array}{l}\text { Mean baseline } \\
\text { plasma glucose } \\
(\text { mmol/l) }\end{array}$ & $\begin{array}{l}\text { Mean peak } \\
\text { plasma glucose } \\
\text { (mmolll) }\end{array}$ & $\mathbf{P}$ \\
\hline \multirow{3}{*}{$\begin{array}{l}\text { Admission } \\
\text { Day } 3 \\
\text { Discharge } \\
\text { P (admission } \\
v \text { (day 3) } \\
\text { P admission } \\
v \text { discharge) }\end{array}$} & $\begin{array}{l}30 \cdot 5 \pm 47 \cdot 6 \\
15 \cdot 5 \pm 6 \cdot 5 \\
15 \cdot 2 \pm 5 \cdot 9\end{array}$ & $\begin{array}{l}63 \cdot 3 \pm 58 \cdot 6 \\
45 \cdot 4 \pm 41 \cdot 6 \\
36 \cdot 6 \pm 14 \cdot 2\end{array}$ & $\begin{array}{l}\text { NS } \\
<0.01 \\
<0.002\end{array}$ & $\begin{array}{l}6 \cdot 23 \pm 1 \cdot 85 \\
5 \cdot 02 \pm 1 \cdot 06 \\
4 \cdot 48 \pm 0 \cdot 45\end{array}$ & $\begin{array}{l}7 \cdot 00 \pm 1 \cdot 25 \\
6 \cdot 03 \pm 1 \cdot 20 \\
5 \cdot 28 \pm 0 \cdot 92\end{array}$ & $\begin{array}{l}\text { NS } \\
\text { NS } \\
<0.05\end{array}$ \\
\hline & NS & NS & & NS & NS & \\
\hline & NS & NS & & $<0.01$ & $<0.002$ & \\
\hline
\end{tabular}

levels rose significantly on the recovery and discharge days but not on the admission day (Table 4). There were no significant differences between the mean peak values obtained on any day.

The mean time taken to reach peak plasma insulin was $14 \pm 8$ minutes.

\section{GLUCOSE}

As patients on admission had not been fasting, the mean baseline plasma glucose was slightly higher on admission than on subsequent days $(P<0.05)$. After the infusion of salbutamol there was no significant rise in plasma glucose.

\section{Discussion}

Intravenous salbutamol has been shown previously to cause a rise in free fatty acids, insulin, and glucose and a fall in potassium in normal subjects (Goldberg et al., 1975; Leitch et al., 1976). There have been very few previous studies of the metabolic changes in acute severe asthma. Tickner et al. (1977) showed a profound metabolic disturbance in patients admitted in acute severe asthma but demonstrated no significant changes in free fatty acids, insulin or glucose after a combination of intravenous aminophylline with an infusion of salbutamol at $10 \mu \mathrm{g} /$ minute.

Neville et al. (1977) showed that stable asthmatics given intravenous salbutamol, $4 \mu \mathrm{g} / \mathrm{kg}$ over 5 minutes, had a significant rise in plasma glucose and insulin and a fall in plasma potassium. They also showed raised baseline free fatty acid levels without a further significant rise after the salbutamol infusion. However, the free fatty acids were estimated for only 10 minutes after infusion.

Our results differ in that we have shown significant rises in free fatty acids and insulin after a 10 -minute infusion of salbutamol, $4 \mu \mathrm{g} / \mathrm{kg}$. These differences may relate to the different rates of administration and the timing of measurements. Moreover, while initial levels of free fatty acids were raised in our patients, in keeping with the metabolic response to the stress of their illness, fasting levels had still not fallen to within the normal range at the time of discharge.

It is recognised that in acute myocardial infarction arrhythmias may be associated with high levels of free fatty acids (Oliver et al., 1968; Rutenberg et al., 1969). While the situation in acute asthma is different, in that the myocardium is usually normal, there remains the theoretical danger of precipitation of arrhythmias by sympathetic stimulation coupled with hypoxaemia. Moreover, there is a well-recognised danger of hypokalaemia in the treatment of severe asthma with high-dose corticosteroids which may be made worse with salbutamol administration. While, in our experience, arrhythmias have not been a feature of the use of intravenous salbutamol, we feel that further studies of the dose and method of administration of this drug should take account of the possibility. In addition, it remains essential to monitor potassium in the management of this disease.

In this study no patient failed to respond to intravenous salbutamol, either by a rise in peak flow rate or by metabolic changes. This accords with our previous experience that $\beta$ receptor blockade rarely occurs in acute severe asthma (Williams et al., 1975; Williams and Seaton, 1977).

We thank Dr. L. Martin and Mr. J. Davies of Allen and Hanburys who provided assay services, and Dr. S. J. Williams for advice and helpful suggestions.

\section{References}

Carruthers, M., and Young, D. A. B. (1973). Free fatty acid estimation by a semi-automated fluorimetric method. Clinica Chimica Acta, 49, 341-348.

Dole, V. P. (1956). A relation between non-esterified fatty acids in plasma and the metabolism of glucose. Journal of Clinical Investigation, 35, 150-154.

Goldberg, R., Van As, M., Joffe, B. I., Krut, L., Bersohn, I., and Seftel, H. C. (1975). Metabolic responses to selective $\beta$-adrenergic stimulation in mean. Postgraduate Medical Journal, 51, 53-58. 
Johnson, A. J., Pidgeon, J., Bateman, S., and Spiro, S. G. (1976). Comparison of aminophylline and salbutamol infusion in the treatment of acute attacks of asthma. Thorax, 31, 239-240.

Leitch, A. G., Clancy, L. J., Costello, J. F., and Flenley, D. C. (1976). Effect of intravenous infusion of salbutamol on ventilatory response to carbon dioxide and hypoxia and on heart rate and plasma potassium in normal men. British Medical Journal, 1, 365-367.

Liggins, G. C., and Vaughan, G. S. (1973). Intravenous infusion of salbutamol in the management of premature labour. Journal of Obstetrics and Gynaecology of the British Commonwealth, 80, 29-33.

May, C. S., Spiro, S. G., Johnson, A. J., and Paterson, J. W. (1975). Intravenous infusion of salbutamol in the management of asthma (Abstract). Thorax, 30, 236.

Neville, A., Palmer, J. B. D., Gaddie, J., May, C. S., Palmer, K. N. V., and Murchison, L. E. (1977). Metabolic effects of salbutamol: comparison of aerosol and intravenous administration. British Medical Journal, 1, 413-414.

Oliver, M. F., Kurien, V. A., and Greenwood, T. W.
(1968). Relation between serum-free-fatty-acids and $\stackrel{\overrightarrow{\vec{F}}}{\overrightarrow{7}}$ arrhythmias and death after acute myocardialo infarction. Lancet, 1, 710-715.

Rutenberg, H. L., Pamintuan, J. C., and Soloff, L. A.⿳亠二口犬 (1969). Serum-free-fatty-acids and their relation to $\vec{\widetilde{ }}$ complications after acute myocardial infarction. 을 Lancet, 2, 559-564.

Tickner, T. R., Cramp, D. G., Foo, A. Y., Johnson, $\vec{\circ}$ A. J., Bateman, S. M., Pidgeon, J., Spiro, S. G., Clarke, S. W., and Wills, M. R. (1977). Metabolic $\vec{\omega}$ response to intravenous salbutamol therapy in acuteo asthma. Thorax, 32, 182-184.

Williams, S. J., Parrish, R. W., and Seaton, A. (1965) $\stackrel{\vec{\omega}}{\dot{\omega}}$ Comparison of intravenous aminophylline and sal- $\mathrm{N}$ butamol in severe asthma. British Medical Journal, or 4,685 .

Williams, S. J., and Seaton, A. (1977). Intravenous or inhaled salbutamol in severe acute asthma? Thorax (In press).

Requests for reprints to: Dr. A. Seaton, Asthma Research Unit, Sully Hospital, Penarth, South Glamorgan, CF6 2YA, UK. 